\title{
P-34 BIG'95 - A RECENT DEBRIS FLOW IN THE EBRO CONTINENTAL SLOPE, NORTHWESTERN MEDITERRANEAN
}

\author{
${ }^{1}$ Barcelona University, GRC en Geociències Marines, Departas, \\ Facultat de Geologia, Campus de Pedralbes, 08028 Barcelona, Spain \\ 'Laval University
}

\section{Summary}

A Recent debris flow (named BIG'95) on the Ebro slope (North-western Mediterranean) is reported in this study and examined by means of swath bathymetry, high and very highresolution seismic records, TOBI side-scan sonar, and coring. Here we present the preliminary results of this study, including geometry, description and dating of the debris flow, as well as a first move towards its triggering mechanisms.

\section{Introduction}

During a survey onboard the R/V Hespérides in 1995, a landslide was discovered, named from here onwards BIG'95, on the Ebro margin slope (North-western Mediterranean). Since oil platforms and phone and electric cables are present in the Ebro margin, an immediate and accurate study of the landslide was approved in order to determine its triggering mechanisms and the potential of the Ebro slope for future instability events. In consequence the landslide was further investigated in two new surveys onboard the R/V L'Atalante in 1997 , and the $\mathrm{R} / \mathrm{V}$ Hespérides in 1999. The debris flow extends over an area of $\sim 2000 \mathrm{~km}^{2}$, four times the area of the neighbouring Ibiza Island. It is located in front of the city of Castellon (Valencia, Spain), between $39^{\circ} 30^{\prime}$ and $40^{\circ} 10^{\prime} \mathrm{N}$ and $0^{\circ} 55^{\prime}$ and $1^{\circ} 55^{\prime} \mathrm{E}$, at depths ranging from 800 to $2000 \mathrm{~m}$ near the Columbretes Islands, a small volcanic archipelago.

The three surveys carried out in the landslide area have provided a complete set of data, including swath bathymetry, $3.5 \mathrm{kHz}$ records, both conventional mud penetrator and bottom parametric source (BPS), air-gun seismic reflection profiles, deep-towed side-scan sonar (TOBI) and coring.

\section{Geological setting}

The Ebro margin (fig. 1) is located on the western side of Valencia Trough, a structurally controlled depression formed during the Early Miocene that lies between the Balearic Islands and the Iberian Peninsula. A widespread volcanism is present in this area: Columbretes Islands, DSDP sites 122 and 123 (Ryan et al., 1973).

In the Ebro margin Neogene sediments are characterised by a thick progradational sequence of Pliocene to Pleistocene sediments (the Ebro Group, which includes the lower Ebro Clay, mainly Pliocene prograding shales, and the upper Ebro Sand, mainly Pleistocene clastic shelf complex) overlying the Messinian unconformity (Soler et al., 1983; Maillard et al., 1992). The present base-of-slope was formed by series of migrating, laterally developed channel-levee complexes and non-channelled aprons. Several canyons developed during the Pleistocene in this area (Field and Gardner, 1990). 


\section{BIG'95 debris flow}

The BPS records of the first survey carried out in 1995 showed a large sediment body of transparent seismic facies in the southern area of the Ebro slope. This body was related to a large-scale debris flow, forming the very top of the Plio-Quatemary sequence at the base-ofslope, at depths ranging from 800 to $2000 \mathrm{~m}$. Its upper and middle part has a rough rectangular shape $(40 \times 30 \mathrm{~km})$ where flow occurred from the NW to the SE, while its most distal part displays a more elongated tail-like shape and flow occurred from the SW to the NE, partially filling the Valencia Channel. The BIG'95 event had an important impact on the previous seafloor morphology, cutting pre-existing channels in its both southern and northern boundaries, where it additionally buries a channel-levee complex. Its average thickness is $20 \mathrm{~ms}$, but at the base of the head scar it is thicker than $120 \mathrm{~ms}$ (fig.2).

The main scar is located at $1050 \mathrm{~m}$ and is $200 \mathrm{~m}$ high (fig. $3 \mathrm{a}, 3 \mathrm{c}$ ). It extends down into the sedimentary sequence as a tectonic fault related to a dome-like structure of chaotic seismic facies on air-gun seismic reflection profiles (fig. 3a), which has been interpreted as a volcanic dome (Maillard et al., 1992). Upslope the main scar there are some second order scars, and BPS records show a thin $(10 \mathrm{~ms})$ transparent layer overlying stratified sediments (fig. $3 \mathrm{~b}$ ). Downslope the main scar, BPS records show a thick transparent layer overlying sediments with broken stratified reflectors (fig. 3d) as if they had been dragged by the BIG'95 debris flow. In this part, the debris flow has a blocky surface while further downslope, near the partially buried Valencia channel, the debris flow surface becomes flat.

The presence of a buried chaotic sediment body on the air-gun seismic reflection profiles (fig. 3a) at the same location of the BIG'95 debris flow, indicates the recurrence of instability events in this section of the Ebro slope. In addition, other near surface transparent bodies have been reported all along the Ebro slope; however, none of them is as large as the BIG'95.

Seven long piston cores from the area of the debris flow have been opened and described. The base of a thin (20-120 cm) hemipelagic layer that just overlies the debris flow has been dated by AMS using ${ }^{14} \mathrm{C}$, showing an age of $9950 \pm 50$ to $10430 \pm 60$ years BP.

\section{Factors favouring instability}

There are at least three factors that could have contributed to trigger the $\mathrm{BIG}$ ' 95 debris flow, namely:

a. volcanic or tectonic processes associated to the presence of the volcanic archipelago of the Columbretes Islands, such as earthquakes triggered by volcanic activity or the oversteepening due to the emplacement of the dome-like volcanic structure observed just under the main scar.

b. the overloading of the slope by rapid sedimentation enhanced by the presence of a shelf break sedimentary depocentre in the upper parts of the Ebro Group and the consequent instability of the prograding architecture of the slope (Casablanca Unit and Amposta Unit) (Farran and Maldonado, 1990)

c. the overpressure due to sea level rise and an increase of the temperature of the nearbottom water at the end of the last glacial could have lead to a clathrate destabilisation like the one cited by Rothwell et al. (2000) to explain the triggering of the Balearic megaturbidite. Nevertheless, clathrate have never been reported in the Western Mediterranean.

Probably, the combination of some of these processes contributed to a general destabilisation of the Ebro slope, triggering not only the BIG'95 debris flow but also the other smaller debris flows reported in the area.

\section{Acknowledgements}

This study was supported by the EC-VFP project COSTA (Continental Slope Stability, EVK3-1999-00028), CYTMAR project GRANDES (MAR98-0347), Generalitat de Catalunya 
Grups de Recerca Consolidats and Ministerio de Educación y Cultura fellowship (Galderic Lastras).

\section{References}

Farran, M. and Maldonado, A., 1990. The Ebro continental shelf: Quaternary seismic stratigraphy and growth patterns. In: C.H. Nelson and A. Maldonado (Ed.), The Ebro Continental Margin, Northwestern Mediterranean Sea. Marine Geology, 95: 289-312.

Field, M.E. and Gardner, J.V., 1990. Pliocene-Pleistocene growth of the Rio Ebro margin, northeast Spain: A prograding-slope model. Geological Society of America Bulletin, 102: 721-733.

Maillard, A., Mauffret, A., Watts, A.B., Torné, M., Pascal, G., Buhl, P. and Pinet, B., 1992. Tertiary sedimentary history and structure of the Valencia trough (western Mediterranean). In: E. Banda and P. Santanach (Ed.), Geology and Geophysics of the Valencia Trough, Western Mediterranean. Tectonophysics, 203: 57-75.

Ryan, W.B.F., Hsu, K.I. et al., 1973. Initial report of the Deep Sea Drilling Project. U.S. Government Printing Office, Washington D.C., volume 13.

Rothwell, R.G., Reeder, M.S., Anastasakis, G., Stow, D.A.V., Thomson, J. and Kähler, G., 2000. Lowstand emplacement of megaturbidites in the Western and Eastern Mediterranean Sea. Sedimentary Geology (in press).

Soler, R., Martínez del Olmo, W., Megías, A.G. and Abeger, J.A., 1983. Rasgos básicos del Neógeno del Mediterráneo Español. Mediterránea Ser. Geol., 1: 71-82.

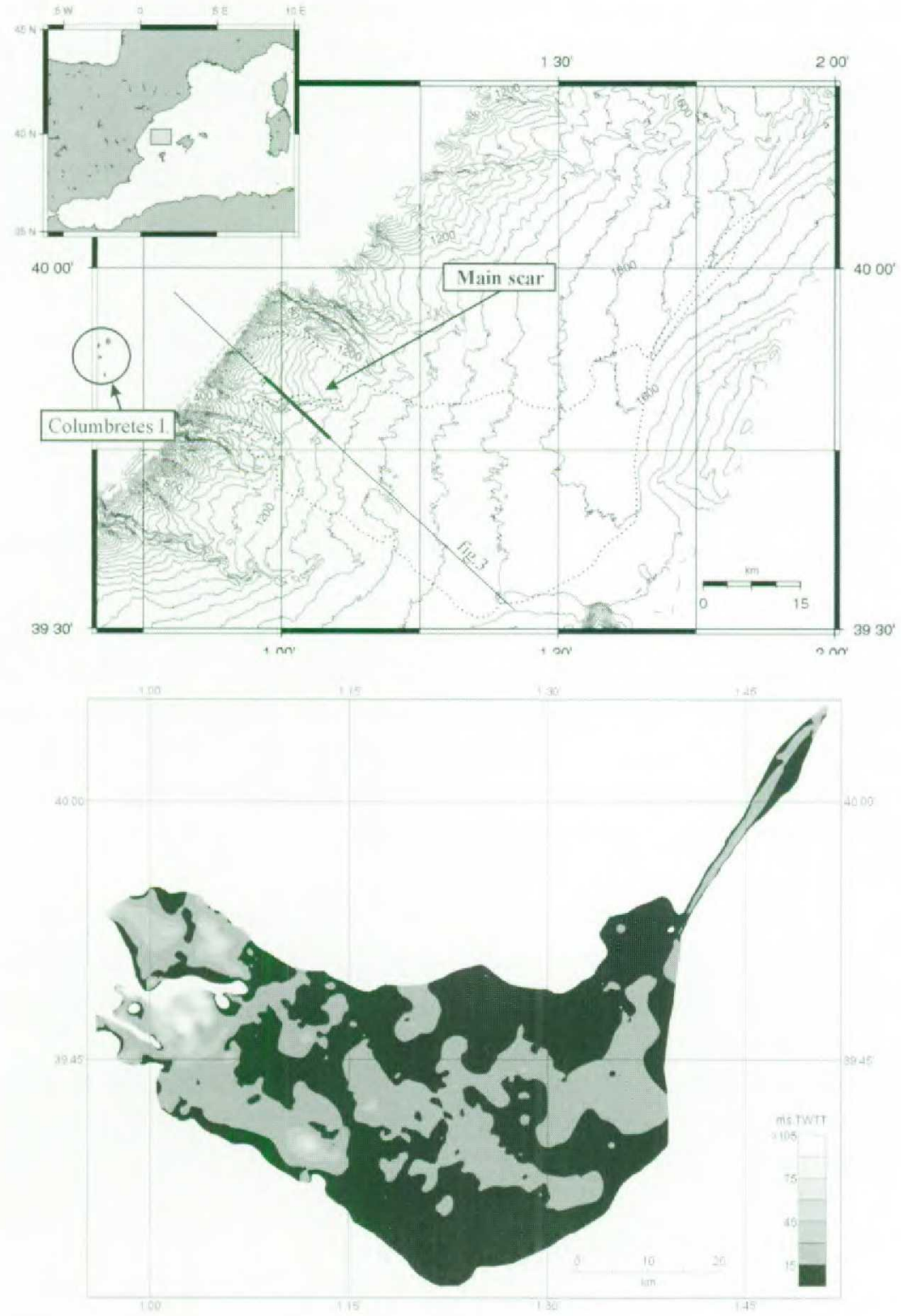

Fig 1 .

Bathymetric chart of the $B I G^{\prime} 95$ debris flow area (limited by the dotted line), showing the debris flow pathway from the slope into the Valencia Channel and the location of the main scar. In the upper left frame, general situation of the studied area.

Fig 2.

Isopach map (ms TWTT) of the BIG'95 debris flow, based on the digitalisation of the BPS profiles. The average thickness is $20 \mathrm{~ms}$, but at the base of the scar the accumulation of sediment is over 120 ms. 


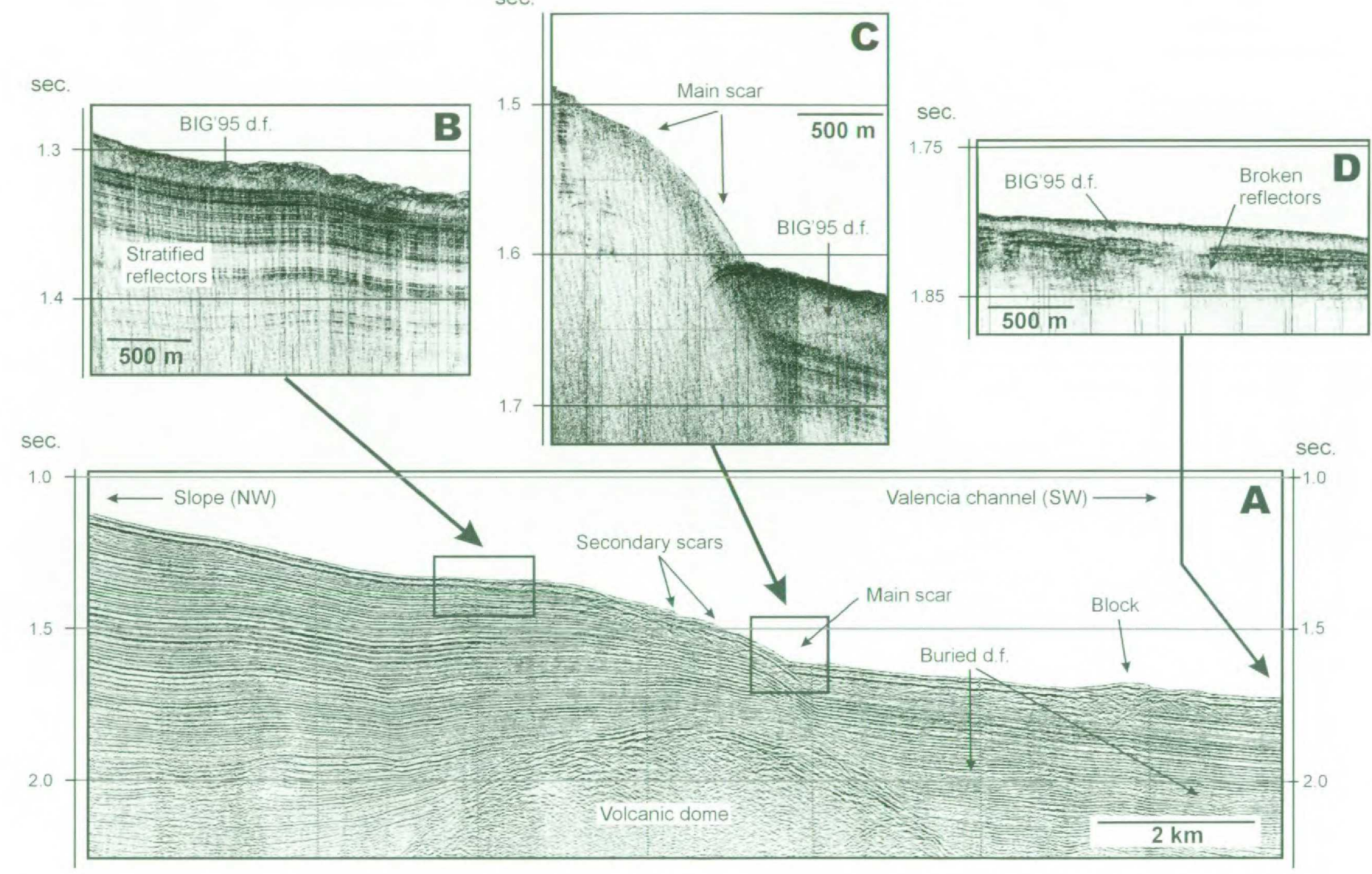

Fig 3. (a) Air-gun profile crossing the BIG'95 debris flow from the Ebro continental slope down to the Valencia Channel. A volcanic dome can be outlined under the main scar of the debris flow. One of the blocks on the surface can be observed. Also, a buried debris flow can be seen at the same location of the recent one indicating the persistence of the instability in this area. (b) BPS profile of the area upslope the scar. showing a thin transparent layer over undisturbed stratified reflectors. (c) BPS profile crossing the scar, where the debris flow gets thicker. (d) BPS profile of the distal part of the debris flow, showing disturbed broken stratified reflectors under the debris flow. 